\title{
sciendo
}

DOI 10.2478/sbe-2019-0017

SBE no. 14(1) 2019

\section{BANKS DIGITALIZATION - A CHALLENGE FOR THE ROMANIAN BANKING SECTOR}

\author{
SBARCEA loana Raluca \\ Lucian Blaga University of Sibiu, Romania
}

\begin{abstract}
:
The banking system has undergone several transformations since its beginning up to now, some as a result of adapting to customers' requirements that have become increasingly sophisticated, and others as a result of the economic and political contexts that have passed, which again - have required its adaptation. Regardless of the situation, the banks have undergone a large digitization process, a process that is now in progress and which in the coming years can cause a significant change in the banking we knew about 10-15 years ago. Through this paper, I propose to analyse the situation of the banking system in terms of adapting to these challenges, at the level of Romania, in the context of the current situation at global and European level, in order to highlight both the progress achieved and the gap in comparison to the other countries, much more competitive from this perspective.
\end{abstract}

Key words: digitization, internet banking, on-line banking

\section{Introduction}

The importance of banking activity in an economy is recognized both at global level, but also at the level of the areas where economic activity is financed mainly through banks. It is the general case of the European economy, which is characterized by a financial system in which banking assets occupy the first position (in the euro area bank assets account for $44.7 \%$ of total financial assets at the end of 2017), but also economies in which the capital market and financial alternatives are not very well developed, such as the Romanian economy, where the assets of credit institutions account for $75.5 \%$ of the total assets of the financial system. (ECB, 2017 and BNR, 2018). In this context, the analysis of the particularities of the banking sector has reflected over the past a technological impact on the banking sector, which has become particularly visible nowadays, as in the specialized analyses, the digital banking concept is increasingly being discussed.

The paper will contain a brief analysis of the literature on the mutations and particularities of current banking systems, but also the concept of digital banking and a 
case study in which I intend to analyse the positioning of the Romanian banking sector in a global and European context and how it adapts to the challenges of the digitization period it goes through.

\section{Literature review}

The banking activity, which appeared at the demand and need of the clients, but also as an activity necessary for a certain level of economic development, has done exactly this throughout history, namely it has been permanently adapted to the needs of the clients and the degree of economic development of each period covered. Switching to certain economies from the centralized system to a market economy has led to a restructuring of the banking system. In this context, Negrus $\mathrm{M}$. emphasizes the role that the bank has, as an intermediary between the economic sectors, by transferring the funds from the richer sectors to the poorer ones. (Negruş, M., 2008). The development of this role also determined the increase of competition in the banking sector, in order to adapt to the increasingly sophisticated requirements of the clients.

This adaptation, to market requirements, to customer requirements is the promoter of financial innovation. Innovation requires adaptation and the creation of new financial products; in a wider sense, new methods are being incorporated to mobilize or place money, or the development and evolution of new financial bodies. Consequently, financial innovation is manifested at the level of the entire financial market, so also at the level of the market for banking products and services (examples of such financial innovations are: interest rate swap, use of credit derivatives, securitization of credits, prepaid debit cards, use intensive Internet banking and its particular forms). (Stoica, O., 2006). As Mr. Isărescu said after the 2008 financial crisis, the innovations will never cease, because they are the ones that increase the efficiency with which the needs of the clients are satisfied. (Isărescu M., 2009). In the literature there is a distinguish between several types of financial innovation, interconnected with each other, from product innovation, which generates new financing products, to process innovation, which makes the way for obtaining funding to be new, up to regulatory and system innovations that integrate other types of innovation into the legal framework and the system of each economy.

These aspects are directly related to the other features of current banking systems, such as deregulation, without which the legality of new products would not have been possible, but also the globalization of banking activity, facilitated mainly by the physical expansion of large banks, but also in virtual space, with the help of the internet.

In this context, the concept of digital banking is being used more and more often lately, but it is also often confused with the term internet banking or mobile banking. So, after analysing the articles, we may say that online banking or internet banking involves banking operations using a desktop device, laptop, tablet, smart phone, and digital banking involves the automation of each stage of banking activity, which makes the visit to the bank's premises unnecessary. Thus, if the existence of internet banking or mobile banking applications requires a prior visit to the bank, the existence of digital banking implies the beginning of the client's relationship with the bank in the virtual environment. 
The emergence of these increasingly competitive services, which in the coming years in the banking activity will be carried out mainly in the on-line environment, has a close connection with the characteristics of the consumers of banking products. Thus, Bergal D. performs an analysis of the behavioural characteristics of current consumers of banking products (millennials - those who were born between 1981-2000), on the website Avoka (multi-sector digital solution platform, member of Temenos, world leader in banking software), which influences the changes in banking activity, and to which digitization solutions should adapt to (Bergal D., 2016). Thus, this generation has lost the idea of attaching itself to a bank or banking culture, over a quarter of those surveyed are willing to change their banking service provider and believes that in 5 years there will be no need for banks in physical form. For those in this generation, the existence of a virtual communication channel with the bank is essential, and $74 \%$ of them think that mobile banking applications are very important to them (almost double in comparison with the previous generation).

This profile which I presented, that of the current banking consumer aged 18-40, makes classical banking activity, which involves face-to-face contact between the client and the bank, no longer necessary, and rather secure, competitive applications to provide fast and easy access to banking services using the virtual environment are needed.

In the case study, I will analyse the use of modern products such as internet banking or mobile banking in Romania compared to EU countries and I will show how much digital banking can be talked about in the Romanian banking sector or rather just about online banking.

\section{Case study}

To begin with, I have positioned my research topic in the international context of global telephony, computer and internet use as the first factor that has helped to direct bank strategies towards delivering services in the virtual space. Thus, analysing the evolution of fixed telephony, mobile telephony subscriptions, households with Internet and individuals using the Internet in the period 2005-2018 (figure no. 1), we can see the following aspects:

3.1 the situation of fixed telephony subscriptions is the only one that reflects a decrease, its place being taken over by subscriptions to mobile telephony;

3.2 a closeness between countries of the world as number of mobile subscriptions per 100 inhabitants, which also recorded an increase in the countries of Africa;

3.3 a significant discrepancy as a percentage of households with an Internet connection between countries in Europe where more than $80 \%$ of households have connections to the country and countries in Africa where the percentage slightly exceeds $20 \%$ or the CIS or Arab countries that have only $50 \%$ households connected to the Internet;

3.4 positioning countries in Europe on the first place as a percentage of individuals using the Internet (over 80\%), with a difference of $10 \%$ compared to the countries of the American continent and the CIS countries. 

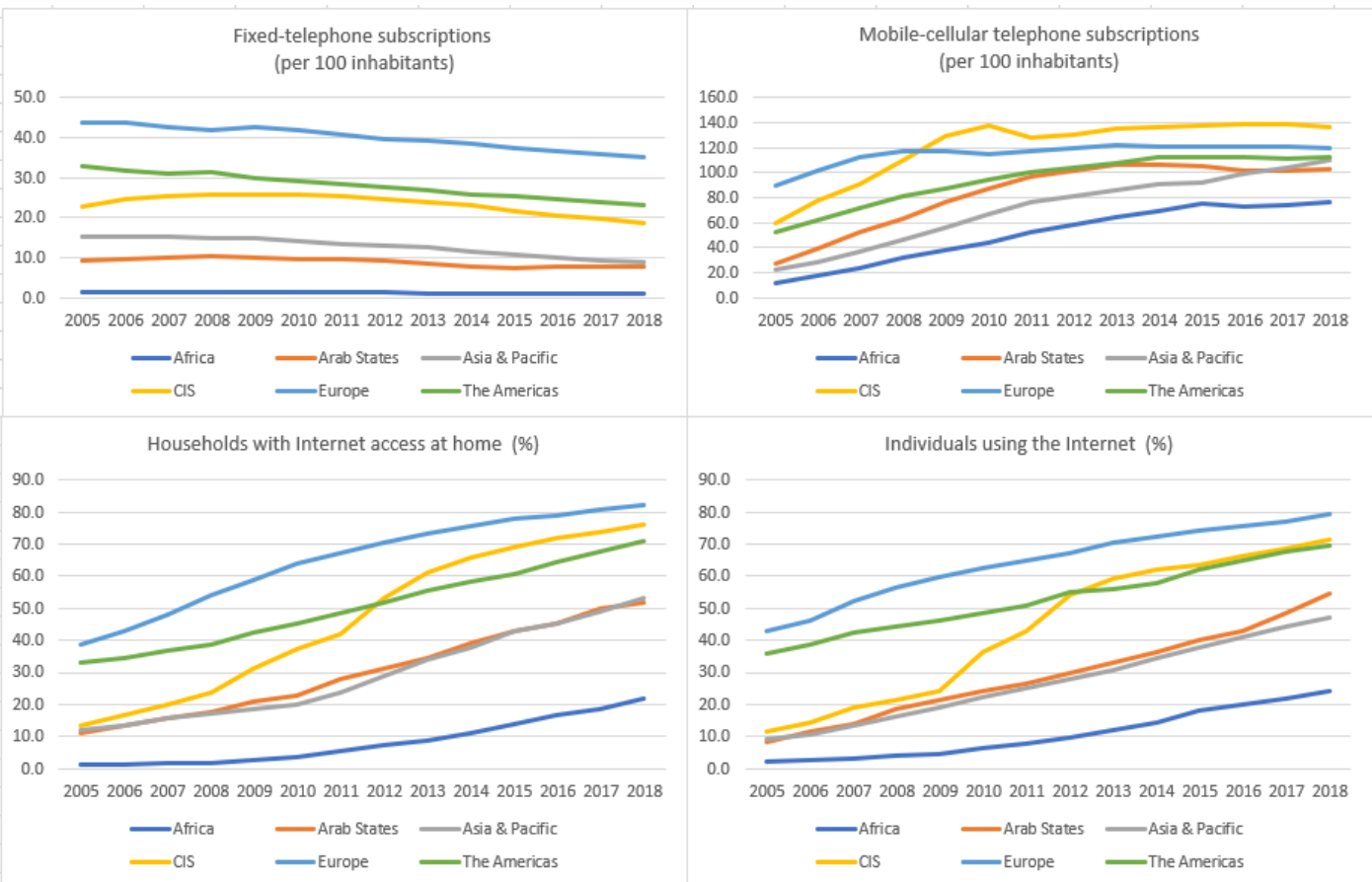

Figure 1: Global evolution of mobile phone subscriptions, fixed telephony, households connected to the Internet and individuals using the Internet between 2005 and 2018

Source: own processing based on data provided by the International Telecommunication Union (ITU) (https://www.itu.int/en/ITU-D/Statistics/Pages/default.aspx)

This analysis reflects a framework conducive to the development of online banking services in European countries, a situation that must also be linked to the fact that the European banking sector has a major position in financing the European economy. Thus, according to World Bank and European Banks Federation data, the total value of bank assets is $216.74 \%$ / GDP in the EU and $210.73 \%$ / GDP in the euro area.

Also, a study by PwC, a financial services company, showed that there is a change in customer preference for a certain type of communication channel in order to access the banking products, respectively an increase in the preference for the use of mobile phones, and a decrease in the percentage of computer use (Figure no. 2).

In this context, it is clear the need for banks to adapt their own strategies to these customer preferences. Another very important element in global payments and lending is the entry of new non-bank players such as Apple, Google, Amazon, or Alibaba that operate globally and have a large number of clients, and thus exert significant competitive pressure on banks. Companies in other sectors, such as mobile operators, are also looking for new revenue opportunities cantered on financial services (Cuesta, C. Tuesta, DA, Ruesta M., Urbiola P., 2015). Banks will have to find the solution to remain attractive in their ongoing work, being permanently present in the on-line environment, and adapting to 
the profile of the current client, who wants speed and simplicity in the operations and the security of payments.

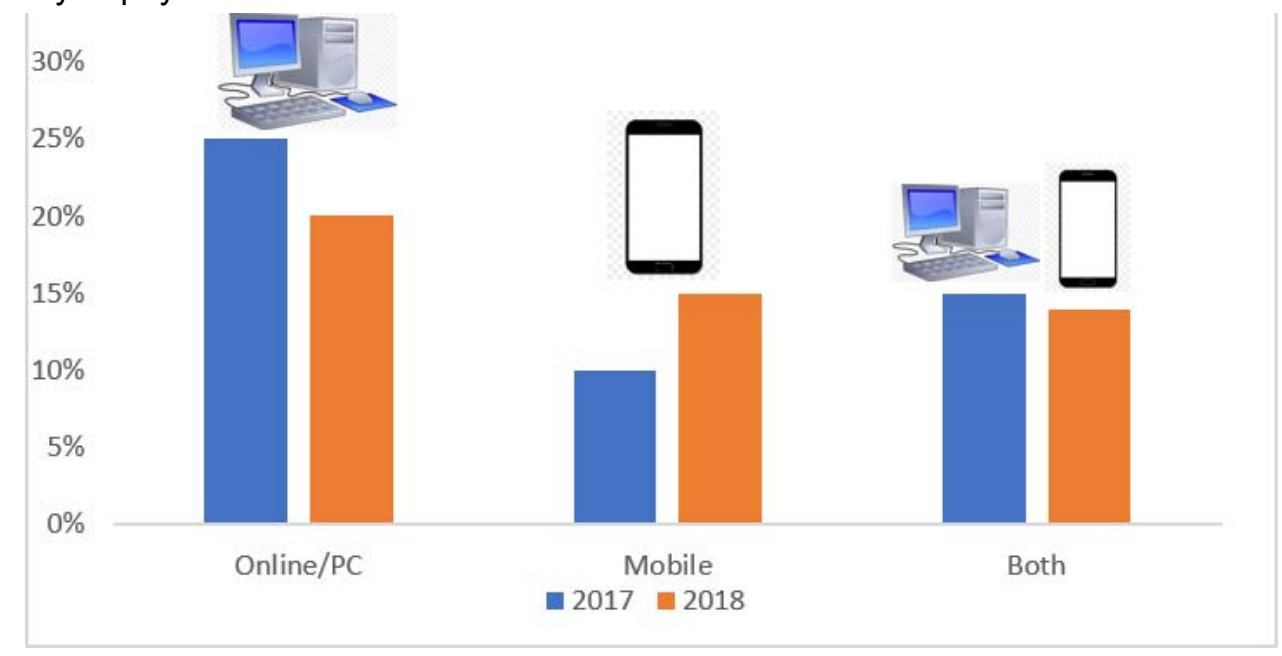

Figure 2: The evolution of the communication channels used by the banking customers

Source: PwC financial services - PwC's 2018 Digital Banking Consumer Survey, June 2018

I will continue to analyse the European banking sector from this perspective of digitization. In analyses conducted in the European banking sector, the term digital is used very often. Thus, according to a study by the European Bank Federation, the expectations for 2020 are that more than $60 \%$ of European banks are digitally mature compared to $19 \%$ in 2018. Expectations are also that 1.9 million consumers banking services to use biometrics and e-identification to access banking operations, which looks like it would impact only the front-office activity of banks, but in fact back-office activity should be adapted to these significant changes. In the future, Artificial Intelligence is likely to be used to carry out these activities, given that, following a study by Accenture, respondents believe that the use of artificial intelligence will generate the following benefits: increasing customer confidence, optimizing costs and operations and an improvement in integration and compliance (Accenture - Banking Technology Vision 2018). According to this study, the impact of the use of artificial intelligence will not lead to a diminution of banking personnel but only a restructuring of it, in the sense of increasing the need for specialized personnel to customize, prepare and ensure the maintenance of robots that will carry out banking activities.

At European level, there is a yearly report that looks to analyse digital progress in European countries, a report highlighting the major discrepancies between member countries. Thus, the Digital Economy and Society Index, which is a composite index that takes into account five aspects: the cost and speed of the Internet connection, people's ability to use the Internet, the use of the Internet for communication and transaction, digitalisation business and eCommerce and also eGovernment services is calculated. Considering the five criteria, Denmark, Finland, Sweden and the Netherlands are the most 
digitized economies, and Italy, Greece, Bulgaria and Romania occupy the last positions in terms of digitization (figure no. 3).

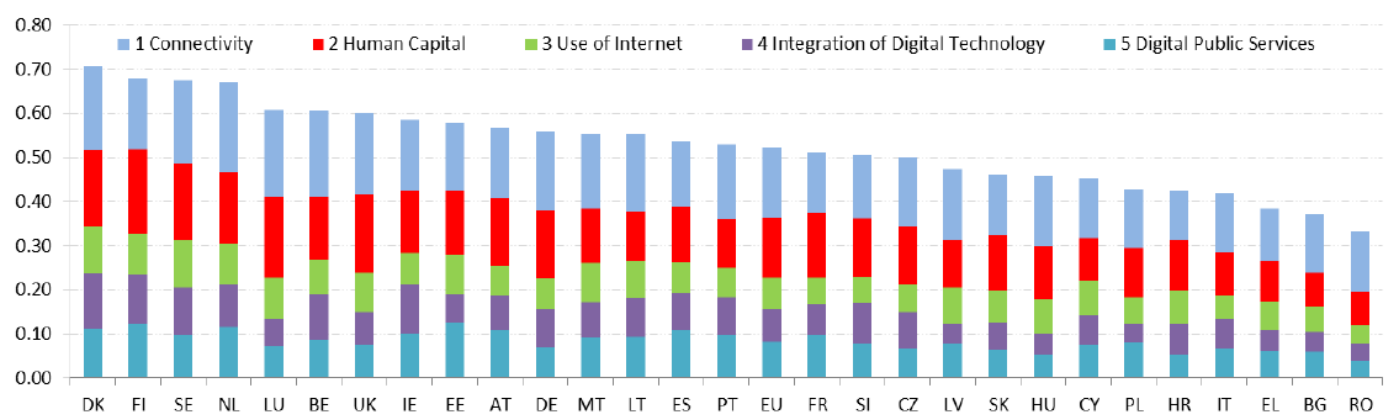

Figure: 3 The ranking of the countries of the European Union from the perspective of the Digital Economy and Society Index in 2017

Source: European Commission - Europe's Digital Progress report 2017, https://ec.europa.eu/digital-singlemarket/en/european-digital-progress-report

Regarding the degree of use of Internet banking services, the EU is once again a place of the extremes. Thus, the percentage of use of on-line banking services is $60 \%$ at EU level, an average percentage of over $90 \%$ for the internet-banking usage in Norway, Finland, the Netherlands and Denmark, and lower than 10\% in 2016 in Romania and Bulgaria (figure no. 4).

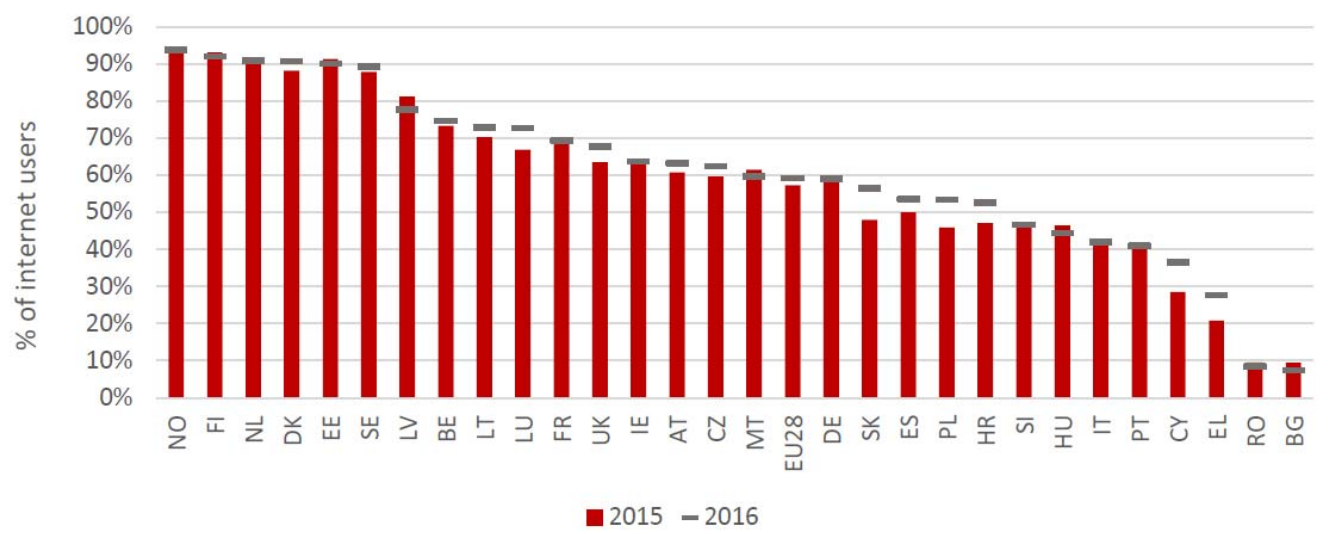

Figure 4: The situation of people using internet banking ( $\%$ of the number of Internet users)

Source: European Commission - Europe's Digital Progress Report 2017, https://ec.europa.eu/digital-single-market/en/european-digital-progress-report

Regarding the situation of digitization in the Romanian banking sector, Romania is part of the European Union, together with highly digitized countries, and if the 
situation as a whole, considering the digitization index, places Romania on the last position, but not at a very large distance from the leading countries (because we look well in terms of connection speed, the connection costs, the use of the Internet for communication), the situation is different in terms of using the Internet for more complex purposes. Thus, there is a major discrepancy between Romania, where only $10 \%$ of internet users use internet banking, and other countries, where on average $60 \%$ of Internet users use on-line banking services, respectively highly digitized countries, where over $90 \%$ of Internet users use internet banking. Other discrepancies highlighted by the Romanian Banking Association (ARB) refer to the fact that in Romania, most of the payments are made in cash (94\% against $68 \%$ in Western Europe), a reduced share of Internet users made purchases on - line ( $23 \%$ compared to $68 \%$ of the European average), and the share of SME online transactions is reduced ( $7 \%$ compared to $17 \%$ of the EU average) (ARB). It is obvious that Romania needs to make investments to reduce this gap, otherwise the gap between Romania and the other countries will grow, which will be detrimental to our country's development and deep integration into the EU and its structures.

Therefore, if we are to analyse the degree of banking digitization in Romania, this term is inappropriate, because at most we can talk about the use of electronic payment instruments such as cards and the use of Internet banking applications and the moment of giving up the direct interface with the bank is more distant than in other countries. The factors that place Romania in the last position in terms of digital issues are different, from high costs, lack of trust in the banking system, lack of usefulness of these services, distance, the fact that one single family account is considered sufficient or lack of financial means (Moroșan, G., 2017).

Since 2015, the National Bank of Romania has been proposing an analysis of the degree of financial inclusion in Romania and the results of the comparative analysis with the other countries in the region reflect a situation that is not at all favourable to the development and adaptation to the new banking and digitization tendencies in our country (table no. 1).

Table 1: Indicators of financial inclusion in Romania compared to the countries in the area

\begin{tabular}{|l|c|c|c|c|}
\hline \multicolumn{1}{|c|}{ The indicator analysed } & Romania & Bulgaria & Poland & Hungary \\
\hline $\begin{array}{l}\text { \% of the adult population holding a } \\
\text { bank account }\end{array}$ & 58 & 72 & 87 & 75 \\
\hline number of debit cards (mil) & 13,6 & 6,5 & 30,5 & 7,7 \\
\hline number of credit cards (mil) & 2,8 & 1 & 5,8 & 1,4 \\
\hline $\begin{array}{l}\% \text { of the adult population using a } \\
\text { debit card to make payments }\end{array}$ & 24 & 35 & 73 & 54 \\
\hline $\begin{array}{l}\text { \% of the adult population paying bills } \\
\text { and / or making online payments }\end{array}$ & 19 & 26 & 65 & 38 \\
\hline number of ATMs per 100,000 adults & 66 & 95 & 69 & 60 \\
\hline
\end{tabular}

Source: Processing after the NBR - Financial Stability Report, December 2018

Analysing this situation, we observe a somewhat paradoxical situation. Thus, although the number of cards in circulation in Romania is higher than the number of cards 
in circulation in Hungary and Bulgaria, the percentage of using debit cards or on-line means to make payments is the lowest. This suggests a rudimentary use of cards, in a large proportion only for withdrawing cash, and in a reduced proportion for more complex functions. This aspect in fact reflects a reduced banking culture among consumers of banking products and services. Another aspect to be considered from this perspective is related to the major disparities in development between the regions of Romania, although the urban population is $57.92 \%$ and in the rural area $42.08 \%$ (an average number that includes areas where the rural population is only $8.4 \%$ and areas where it is $57 \%$, according to the data provided by the National Institute of Statistics), the difference is significant between the percentage of the urban adult population that has a bank account and the percentage of the rural population holding an account. There is no data on the use of structured Internet banking services by customer's background, but certainly $20-24 \%$ is derived from an average utilization rate of over $50 \%$ in urban areas and very low in rural areas. This aspect is strictly related to the level of knowledge that presents major differences in Romania, between the development regions. (figure no. 5).

The rural population $(42,08 \%$ of the total population)

The urban population $(57,92 \%$ of the total population)

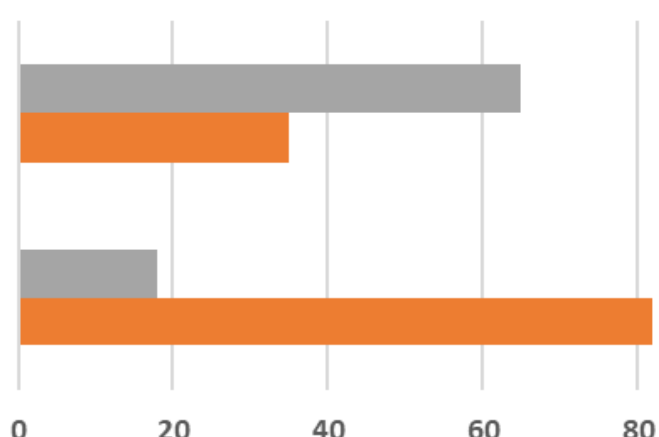

Do not have a bank account $\quad$ Have a bank account

Figure 5: Structuring the population and bank account holdrs according to the home environment

Source: processing by INSSE data

http://www.insse.ro/cms/files/publicati//pliante\%20statistice/Populatia\%20Romaniei\%20pe\%20localitati\%20la\%20

1\%20ian\%202015.pdf and Ziarul Capital - https://www.capital.ro/2017-anul-extinderii-serviciilor-bancare-in-zonarurala-1.html

These aspects of malfunctioning and disparity do not meet an increase in the expansion banks' intentions in rural areas, nor the prioritization of investment in digitization. Thus, the analysis of the priority objectives of the Romanian banks shows a position of the investments in automation only on the 4th position, the first 3 positions being related to risk reduction (figure no.6). 


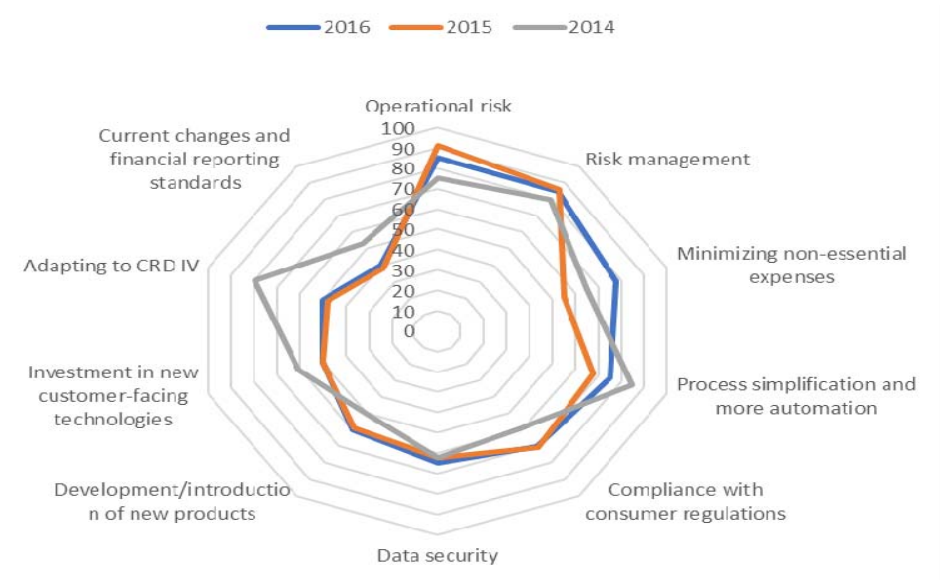

Figure 6: Situation of priorities in the Romanian banking sector

Source: processing after the ARB \& EY 2016 Banking Barometer, https://www.arb.ro/barometrul-bancar-arb-ey2016-creste-interesul-pentru-achizitionarea-de-active-si-parteneriate/

We note that there is no significant change between banks' priorities in 2016 compared to 2015, perhaps only a greater emphasis on minimizing non-essential expenditure and simplification of processes and more automation, although difficult to understand given the upshot of digitization in other countries, the percentage for this automation priority decreased compared to 2014 .

\section{Conclusions}

The banking sector has been constantly undergoing changes, starting with primitive asset-bearing activities, and to extremely complex activities today. The change was dictated by general economic developments, changes in the behaviour of consumers of banking services and the impact technology had on the banking sector. And nowadays, technology and digitization are one of the defining features of the developed banking sectors and one of the biggest challenges in banking for developing economies, as is the case with Romania.

The analysis we have made has revealed an accelerated dynamics in the use of mobile telephony and the Internet that has facilitated the use of banking services that use them, such as internet banking and mobile banking, the use of mobile phones overcoming the use of computers for access to on-line banking services. The analysis also highlighted the differing pace of use of these modern services, both globally, with countries in America, Europe being in the top positions, but also within the European Union, where Internet banking usage rates range from $10 \%$ to $90 \%$.

In this context, the Romanian banking sector, although it is the main sponsor of the local economy, fails to assimilate very much from this digitization process. Thus, although we have the internet quite present in households, and we benefit from networks offering high speed and low costs, it is mainly used for communication and much less for accessing online banking products. Thus, our country is in the next to last position in the EU in terms of the percentage of those who have used internet banking in relation to internet users 
(below 10\%). The reasons invoked are diverse and reflect a lack of knowledge of the benefits these services offer, which makes Internet users lack confidence and continue to prefer classic banking. Another aspect that we have outlined is that we also see within Romania the major disparities between the developed regions, so we are witnessing the situation where there is a significant population in rural areas, and even though networks which offer internet access have penetrated there, the degree of use of internet banking is very low. This happens given that only $35 \%$ of the rural population have bank accounts, compared to $82 \%$ of the urban population. This situation related to the reduced digitization, especially in certain areas of Romania, is also due to the lack of investments by banks in expanding in rural areas and in the provision of financial education to their own clients.

I believe that in Romania, as an EU member and future member of the euro area, there should be a strategy at both national and at banks' level to increase investment in financial education that leads to knowledge of the benefits of banking products offered in the on-line environment, which will lead to diminished discrepancies that exist between the Romanian consumers of banking products and those from other countries, but especially to reduce the disparities that exist within the country between the different development regions.

\section{References}

Cuesta, C. Tuesta, DA, Ruesta M., Urbiola P. - The digital transformation of the banking industry, August 2015, https://www.researchgate.net/publication/291357544

Moroșan, G. - Aspects of digitalization of the activity in the banking system in Romania, European Journal pf Accounting, Finance \& Business, Volume 5 / 2017

Negruş, Mariana - Banking products, services and marketing, Publisher: Fundaţa România de Mâine, Bucureşti, 2008, pp. 20

Stoica, O. - Financial innovation and capital markets development, University Al. I.Cuza from laşi Annals, Tomul LII/LIII, 2005/2006, pp. 77-78

Accenture - Banking Technology Vision 2018

RAB \& EY 2016 Banking Barometer, https://www.arb.ro/barometrul-bancar-arb-ey-2016-creste-interesulpentru-achizitionarea-de-active-si-parteneriate/

RAB - Digital Agenda and Cyber Security, https://www.arb.ro/agenda-digitala-si-securitatea-cibernetica/

NBR - Isărescu M. - Nine lessons from the current financial crisis, 2009, www.bnro.ro

NBR - Financial Stability Report, December 2018, www.bnro.ro

ECB - Report on Financial Structures, October 2017, www.ecb.int

European Commission - Europe's Digital Progress report 2017, https://ec.europa.eu/digital-singlemarket/en/european-digital-progress-report

International Telecommunication Union (ITU) (https://www.itu.int/en/ITU-D/Statistics/Pages/default.aspx)

PwC financial services - PwC's 2018 Digital Banking Consumer Survey, June 2018

www.linkedin.com/pulse/digital-vs-mobile-banking-differences-nnamdi-azodo

https://www.avoka.com/blog/top-millennial-banking-trends/ - Bergal Don - Top Millennial Banking Trends That Banks Need to Know, April 25, 2016

http://www.insse.ro/cms/files/publicatii/pliante\%20statistice/Populatia\%20Romaniei\%20pe\%20localitati\%20 la \%201\%20ian\%202015.pdf

https://www.capital.ro/2017-anul-extinderii-serviciilor-bancare-in-zona-rurala-1.html

https://data.worldbank.org/

https://www.ebf.eu/ 